\title{
Ozone uptake at night is more damaging to plants than equivalent day-time flux
}

\author{
Eleni Goumenaki ${ }^{1,2}$ (I) $\cdot$ Ignacio González-Fernández ${ }^{1,3} \cdot$ Jeremy D. Barnes ${ }^{1}$
}

Received: 26 October 2020 / Accepted: 30 January 2021 / Published online: 24 February 2021

(c) The Author(s) 2021

\begin{abstract}
Main conclusion Plants exposed to equivalent ozone fluxes administered during day-time versus night-time exhibited greater losses in biomass at night and this finding is attributed to night-time depletion of cell wall-localised ascorbate.
\end{abstract}

Abstract The present study employed Lactuca sativa and its closest wild relative, L. serriola, to explore the relative sensitivity of plants to ozone-induced oxidative stress during day-time versus night-time. By controlling atmospheric ozone concentration and measuring stomatal conductance, equivalent ozone uptake into leaves was engineered during day and night, and consequences on productivity and net $\mathrm{CO}_{2}$ assimilation rate were determined. Biomass losses attributable to ozone were significantly greater when an equivalent dose of ozone was taken-up by foliage at night compared to the day. Linkages between ozone impacts and ascorbic acid (AA) content, redox status and cellular compartmentation were probed in both species. Leaf AA pools were depleted by exposure of plants to darkness, and then AA levels in the apoplast and symplast were monitored on subsequent transfer of plants to the light. Apoplast AA appeared to be more affected by light-dark transition than the symplast pool. Moreover, equivalent ozone fluxes administered to leaves with contrasting AA levels resulted in contrasting effects on the light-saturated rate of $\mathrm{CO}_{2}$ assimilation $\left(A_{\text {sat }}\right)$ in both species. Once apoplast AA content recovered to pre-treatment levels, the same ozone flux resulted in no impacts on $A_{\text {sat }}$. The results of the present investigation reveal that plants are significantly more sensitive to equivalent ozone fluxes taken-up at night compared with those during the day and were consistent with diel shifts in apoplast AA content and/or redox status. Furthermore, findings suggest that some thought should be given to weighing regional models of ozone impacts for extraordinary night-time ozone impacts.

Keywords Diel ozone sensitivity $\cdot$ Night-time exposure $\cdot$ Ozone detoxification and repair $\cdot$ Air pollution Climate change

\section{Introduction}

Communicated by Anastasios Melis.

Eleni Goumenaki

egoumen@hmu.gr

1 Plant and Microbial Biology, School of Natural and Environmental Science [SNES], Devonshire Building, Newcastle University, Newcastle Upon Tyne NE1 7RU, UK

2 School of Agricultural Sciences, Hellenic Mediterranean University, P.O. Box 1939, GR-71004 Heraklion, Crete, Greece

3 Ecotoxicology of Air Pollution, CIEMAT, Avda. Complutense, 40.28040 Madrid, Spain
There is growing concern over the impacts of rising tropospheric ozone levels on crop yield in many parts of the world, since this pollutant is likely to continue to negatively influence food supplies for the foreseeable future (Mills et al. 2018; Ainsworth et al. 2020). Exposure to elevated levels of ozone results in detrimental effects on vegetation following uptake into plant foliage via open stomata, where it rapidly decomposes in the cell walls of leaf mesophyll cells to yield a host of Reactive Oxygen Species (ROS; Agathokleous et al. 2020; Foyer et al. 2020). This sequence of events propagates a dramatic and resource-expensive shift in gene expression, reflected in a decline in photosynthetic capacity, retention of fixed carbon in source leaves and the up-regulation of repair and defence networks which is ultimately 
manifested in reduced productivity (Goumenaki et al. 2010; Gillespie et al. 2015).

Ozone pollution is generally perceived as a day-time problem, since the gas is generated as a result of complex photolytic reactions involving nitrogen oxides and volatile organic carbons and the stomata of most plants are commonly open during the day under favourable conditions, enabling ozone uptake into foliage (Royal Society 2008). However, there are many situations, where elevated ozone concentrations are also experienced at night concurrent with situations where plants may exhibit significant stomatal conductance, for example during significant episodes in the Mediterranean region (Kourtidis et al. 2002; Mavrakis et al. 2010; Kopanakis et al. 2016) and in the uplands and wetlands in other areas (Elvira et al. 2016; Warmiński and Bęś 2018). Moreover, night-time ground-level ozone concentrations are reported to be increasing in areas, where $\mathrm{NO}_{\mathrm{x}}$ emissions are rising, as part of a global change in the diurnal cycle of the pollutant (Strode et al. 2019). It is widely reported that exposure to ozone pollution reduces stomatal perception and response to environmental factors. This is known as 'stomatal sluggishness', a condition that persists through the night in multiple species (Paoletti and Grulke 2010; Hoshika et al. 2016; Grulke and Heath 2020). This sluggishness causes additional ozone uptake and reduced water use efficiency (Emberson 2020) and maybe influenced by nutrient supply (Hoshika et al. 2019). Indeed, there is growing recognition that night-time stomatal ozone uptake maybe significant in many wild and cultivated species (Caird et al. 2007; Mereu et al. 2009; González-Fernández et al. 2010; Grantz et al. 2016).

Under occasional conditions, where ozone concentration remains elevated at night it is important to know whether ozone taken-up into the leaf interior at night is significantly more damaging than the equivalent flux taken up during the day. This is also a key factor requiring dial-in to models relating to ozone impacts on vegetation, particularly in the Mediterranean region (Millán et al. 2000; Goumenaki et al. 2007; Pleijel et al. 2007; Grünhage et al. 2012; GonzálezFernández et al. 2013, 2014; Elvira et al. 2016; Querol et al. 2018). Current flux-based ozone risk assessment models, adopted by the UNECE Convention on Long-Range Transboundary Air Pollution for negotiating air pollution abatement protocols, assume minimal night time stomatal conductance (CLRTAP 2017).

A principal factor controlling ozone tolerance is believed to be the composition of the cell wall matrix bounding leaf mesophyll cells, and in particular the level, regeneration rate and redox status of ascorbic acid (AA) in this sub-cellular compartment (Plöchl et al. 2000; Turcsànyi et al. 2000; Sanmartin et al. 2003; Yendrek et al. 2015). The level and redox status of AA in the leaf apoplast may combat ozoneinduced oxidative stress through direct quenching of the resulting ROS and/or the regulation of defence-related gene expression (Noctor et al. 2018). The dynamics of AA catabolism in the apoplast, and transfer from the cytosol, probably play a critical role in determining plant responses to ozone stress (Barnes et al. 2002; Vainonen and Kangasjärvi 2015; Dai et al. 2020) and have been revealed by QTL pyramiding exercises to be amongst the most important and distinct genetic traits governing the tolerance of rice (Frei et al. 2008, 2010) and wheat (Feng et al. 2010; Barnes and Quarrie, unpublished) to elevated levels of ozone. Ascorbate levels in cellular and subcellular compartments are the product of net biosynthesis, recycling, degradation/oxidation and/or intercellular and intracellular transport (Mellidou and Kanellis 2017; Foyer et al. 2020). Light, as well as other environmental factors, are known to directly regulate ascorbic acid metabolic pathways (Ntagkas et al. 2018). Exposure of lettuce to contrasting light regimes results in the upregulation of transcript levels of GMP (GDP-d-mannose pyrophosphorylase), GME (GDP-d-mannose 3'5-epimerase), GGP (GDPL-galactose phosphorylase), GPP (L-galactose-1-phosphate phosphatase), and GLDH (L-galactono-1,4-lactone dehydrogenase) which encode key enzymes in the GDP-L-galactose phosphorylase and GDP-D-mannose-3,5-epimerase biosynthetic pathways (Zha et al. 2020).

Cell wall-localised AA content has been shown to be correlated with $\mathrm{O}_{3}$ tolerance in several studies (Lyons et al. 1999; Turcsànyi et al. 2000; Maddison et al. 2002; Padu et al. 2005). This contention is also supported by research on the targeted transgenic manipulation of apoplast ascorbate content/redox status (Sanmartin et al. 2003; Pignocchi et al. 2006; Ueda et al. 2015). Current views suggest that it probably is the regulation of AA content in the apoplast that modulates responses to ozone-induced oxidative stress rather than AA content per se (Zechmann 2018) and highlight the need for further research related to AA involvement in plant responses and recovery mechanisms after detrimental exposure (Bellini and De Tullio, 2019).

There is little information on diel variations in cell wall-localised AA content. However, Moldau and coworkers (1998) reported a marked decline in AA content at night-time in barley (Hordeum vulgare), and it is known that transfer of plants from high to low irradiance results in marked and rapid shifts in leaf AA content (Gest et al. 2013), expected to be mirrored in shifts in the cell walllocalised AA pool. This raises the question as to whether ozone uptake at night is especially damaging for plants.

In the present study, we probed the linkage between AA content, redox status of the leaf apoplast (and symplast) and ozone injury in L. sativa cv. Paris Island, as well as its closest wild relative, $L$. serriola to investigate any intrinsic interspecific variation. Light levels were used to manipulate sub-cellular pools of AA. Plants were exposed to prolonged darkness to reduce AA in the leaf cell walls. Shifts in 
AA were monitored on subsequent transfer of plants to the light. Stomatal conductance was measured in parallel with atmospheric ozone exposure, and this was used to deliver equivalent ozone fluxes to leaves with contrasting AA levels. Ozone impacts were assessed via impacts on growth and shifts in diagnostic leaf gas exchange.

\section{Materials and methods}

\section{Plant culture and sampling protocols}

Seedlings of $L$. sativa cv Paris Island and L. serriola were raised in growth chambers ventilated with charcoal/Purafil ${ }^{\circledR}$ filtered air (CFA) as described in detail elsewhere (Balaguer et al. 1995). Six weeks after emergence, once the seventh true leaf had begun to emerge, plants were transferred to each of 3 unilluminated identical controlled environment chambers and stored in darkness for 12,34 or $60 \mathrm{~h}$. During this 'dark treatment' plants were exposed throughout to carbon dioxide-free air (by diverting the airflow into each chamber through a self-indicating column of soda lime) which reduced the $\mathrm{CO}_{2}$ concentration sufficiently to prevent stomatal closure and facilitate infiltration to enable extraction of apoplast washing fluid (AWF). After $60 \mathrm{~h}$ in the dark, some of the plants were transferred to growth chambers ventilated with CFA and leaf ascorbate content monitored after $2,9,16$, and $24 \mathrm{~h}$ of continuous illumination at a PPFD of $400 \mu \mathrm{mol} \mathrm{m}{ }^{-2} \mathrm{~s}^{-1}$. Eight plants of each species subject to each treatment were transferred to controlled environment chambers ventilated with ozone for 8 hours after 2, 9, 16 and $24 \mathrm{~h}$ 'recovery' in the light. Stomatal conductance $\left(g_{\mathrm{H} 2 \mathrm{O}}\right)$ was monitored during ozone exposure at $1.5 \mathrm{~h}$ intervals. Measurements were made in situ on the abaxial surface of the youngest fully expanded leaf of each plant using a regularly calibrated Delta-T Devices AP-4 porometer (Delta-T Devices, Cambridge, UK). Ozone concentrations inside individual controlled environment chambers were adjusted regularly to ensure equivalent ozone uptake fluxes, calculated on the basis of recorded $g_{\mathrm{H} 2 \mathrm{O}}$ (see Table 1 ; Eq. 1 ).

\section{Diagnostic leaf gas exchange analysis}

The light-saturated rate of $\mathrm{CO}_{2}$ exchange $\left(A_{\text {sat }}\right.$; measured at a photosynthetic photon flux density-PPFD—of $1000 \mu \mathrm{mol} \mathrm{m}^{-2} \mathrm{~s}^{-1}$ ) was recorded on the most recently fullyexpanded leaf ( 6 independent replicates per treatment) using an automated Parkinson leaf cuvette (model AUTO-PLC-B, PP Systems, Hitchin, UK) linked to an infrared gas analyzer (IRGA, model Ciras II, PP Systems, Hitchin, UK). Measurements were made at a cuvette $\mathrm{CO}_{2}$ concentration of $350 \pm 5 \mu \mathrm{mol} \mathrm{CO}_{2} \mathrm{~mol}^{-1}$ dry air employing a leaf temperature of $22 \pm 0.1{ }^{\circ} \mathrm{C}$.

\section{Determination of ascorbate content and cell membrane integrity}

Apoplast AA content and redox status was determined, with some modifications, according to Turcsànyi and co-workers (2000). Approximately $0.5 \mathrm{~g}$ of leaf tissue (representing one

Table 1 Stomatal conductance to water vapour $\left(\mathrm{g}_{\mathrm{H} 2 \mathrm{O}}\right), \mathrm{O}_{3}$ concentrations to which plants were exposed and calculated ozone fluxes for predarkened $(60 \mathrm{~h})$ Lactuca sativa and L. serriola, following transfer after 2, 9, and $24 \mathrm{~h}$ of continuous illumination $\left(\right.$ PPFD of $\left.400 \mu \mathrm{mol} \mathrm{m} \mathrm{s}^{-2} \mathrm{~s}^{-1}\right)$

\begin{tabular}{|c|c|c|c|c|c|c|c|c|c|}
\hline \multirow[t]{2}{*}{ Species } & \multicolumn{3}{|l|}{$2 \mathrm{~h}$} & \multicolumn{3}{|l|}{$9 \mathrm{~h}$} & \multicolumn{3}{|l|}{$24 \mathrm{~h}$} \\
\hline & $\begin{array}{l}g_{\mathrm{H} 2 \mathrm{O}}(\mathrm{mmol} \\
\left.\mathrm{m}^{-2} \mathrm{~s}^{-1}\right)\end{array}$ & $\mathrm{O}_{3}\left(\mathrm{nmol} \mathrm{mol}^{-1}\right)$ & $\begin{array}{l}\text { Flux }(\mathrm{nmol} \\
\left.\mathrm{m}^{-2} \mathrm{~s}^{-1}\right)\end{array}$ & $\begin{array}{l}g_{\mathrm{H} 2 \mathrm{O}}(\mathrm{mmol} \\
\left.\mathrm{m}^{-2} \mathrm{~s}^{-1}\right)\end{array}$ & $\mathrm{O}_{3}\left(\mathrm{nmol} \mathrm{mol}^{-1}\right)$ & $\begin{array}{l}\text { Flux (nmol } \\
\left.\mathrm{m}^{-2} \mathrm{~s}^{-1}\right)\end{array}$ & $\begin{array}{l}g_{\mathrm{H} 2 \mathrm{O}}(\mathrm{mmol} \\
\left.\mathrm{m}^{-2} \mathrm{~s}^{-1}\right)\end{array}$ & $\begin{array}{l}\mathrm{O}_{3}(\mathrm{nmol} \\
\left.\mathrm{mol}^{-1}\right)\end{array}$ & $\begin{array}{l}\text { Flux }(\mathrm{nmol} \\
\left.\mathrm{m}^{-2} \mathrm{~s}^{-1}\right)\end{array}$ \\
\hline \multirow[t]{6}{*}{ L. sativa } & $200 \pm 33$ & 300 & 36,8 & $144 \pm 16$ & 415 & 36,6 & $325 \pm 63$ & 185 & 36,9 \\
\hline & $99 \pm 10$ & 605 & 36,7 & $79 \pm 8$ & 760 & 36,8 & $265 \pm 20$ & 225 & 36,5 \\
\hline & $113 \pm 16$ & 530 & 36,7 & $82 \pm 7$ & 735 & 36,9 & $213 \pm 21$ & 280 & 36,6 \\
\hline & $78 \pm 11$ & 770 & 36,8 & $73 \pm 6$ & 820 & 36,7 & $240 \pm 13$ & 250 & 36,8 \\
\hline & $83 \pm 16$ & 720 & 36,6 & $85 \pm 15$ & 705 & 36,7 & $218 \pm 23$ & 275 & 36,7 \\
\hline & $85 \pm 12$ & 705 & 36,7 & $92 \pm 28$ & 645 & 36,4 & $172 \pm 16$ & 350 & 36,9 \\
\hline \multirow[t]{6}{*}{ L. serriola } & $103 \pm 18$ & 580 & 36,6 & $45 \pm 6$ & 1320 & 36,4 & $187 \pm 17$ & 320 & 36,7 \\
\hline & $58 \pm 7$ & 1030 & 36,6 & $46 \pm 4$ & 1300 & 36,7 & $171 \pm 36$ & 350 & 36,7 \\
\hline & $54 \pm 6$ & 1100 & 36,4 & $47 \pm 4$ & 1270 & 36,6 & $156 \pm 15$ & 385 & 36,8 \\
\hline & $42 \pm 11$ & 1420 & 36,6 & $48 \pm 4$ & 1250 & 36,8 & $133 \pm 9$ & 450 & 36,7 \\
\hline & $34 \pm 10$ & 1750 & 36,5 & $48 \pm 5$ & 1250 & 36,8 & $116 \pm 42$ & 515 & 36,6 \\
\hline & $34 \pm 6$ & 1750 & 36,5 & $45 \pm 4$ & 1320 & 36,4 & $100 \pm 10$ & 600 & 36,8 \\
\hline
\end{tabular}

Stomatal conductance was monitored during exposure to ozone at $1.5 \mathrm{~h}$ intervals, using a porometer. Measurements were made on the abaxial surface of the youngest fully-expanded leaf. Values for $\mathrm{g}_{\mathrm{H} 2 \mathrm{O}}$ represent the mean $\pm \mathrm{SE}$ of at least six independent measurements. Atmospheric ozone concentrations inside the fumigation chambers were adjusted to ensure the delivery of equivalent ozone fluxes, calculated on the basis of recorded $g_{\mathrm{H} 2 \mathrm{O}}$ (Eq. 1) 
half of the most recently fully expanded leaf with the central vascular tissue removed) was vacuum-infiltrated $(-80 \mathrm{kPa}$ for 2-3 min for L. sativa; 3-4 min for $L$. serriola) with ice-cold $100 \mathrm{mM}$ citric acid/potassium phosphate buffer ( $\mathrm{pH}$ 3.0) containing $100 \mathrm{mM} \mathrm{KCl}$ and $0.2 \mathrm{mM}$ DTPA. The time interval between leaf excision and the completion of infiltration was less than $10 \mathrm{~min}$. Immediately after infiltration, leaves were carefully blotted dry with filter paper, reweighed, rolled and carefully inserted into conical tubes made from PTFE ${ }^{\circledR}$ film. These were then placed in $1.5 \mathrm{ml}$ Eppendorf tubes containing $110 \mu \mathrm{l}$ of cold $6 \%$ (w/v) metaphosphoric acid containing 0.2 mM DTPA. Apoplast washing fluid was extracted by centrifugation $(5 \mathrm{~min}, 400 \mathrm{~g}$ for L. sativa; $5 \mathrm{~min}, 1000 \mathrm{~g}$ for L. serriola) at $4{ }^{\circ} \mathrm{C}$. Extracts were kept on ice, in the dark, and assayed immediately. For the determination of AA and DHA in whole leaf extracts (WLEs), ca. $0.1 \mathrm{~g}$ leaf tissue (from the mid-section of the unused half of the same leaf used for the extraction of AWF) was ground in metaphosphoric acid $(6 \% \mathrm{w} / \mathrm{v})$ containing $0.2 \mathrm{mM}$ DTPA and extracts centrifuged at $10,000 \mathrm{~g}$ for $5 \mathrm{~min}$ at $4{ }^{\circ} \mathrm{C}$, prior to the recovery of the supernatant. The content of AA and DHA was determined, using the spectrophotometric method of Takahama and Oniki (1992). For AA, the absorbance of a $100 \mu \mathrm{l}(50 \mu \mathrm{l}$ for WLEs) aliquot of extract was initially measured at $265 \mathrm{~nm}$ in $100 \mathrm{mM}$ potassium phosphate buffer ( $\mathrm{pH}$ 6.1), then re-measured following the addition of ascorbate oxidase (AO; 5 units; EC 1.10.3.3, from Cucurbita sp.; Sigma). Complete oxidation of AA took no longer than 2 min. Dehydroascorbate content was determined in a separate aliquot of $100 \mu \mathrm{l}(50 \mu \mathrm{l}$ for WLEs) of extract. Initial absorbance was recorded as for AA, and then absorbance was re-measured following the addition of 40 mM DL-dithiothreitol (DTT; Sigma). Complete reduction of DHA took no longer than $10 \mathrm{~min}$. Measurements were corrected to account for the absorbance of AO or DTT at $265 \mathrm{~nm}$. An extinction coefficient of $14.5 \mathrm{mM}^{-1} \mathrm{~cm}^{-1}$ for AA at $265 \mathrm{~nm}$ was used to calculate ascorbate and dehydroascorbate content (Nakano and Asada 1981).

The extent of cytoplasmic contamination of recovered AWF was assayed by measuring intracellular 'marker' enzyme activity (glucose-6-phosphate dehydrogenase (G6PDH) in pre-darkened, darkened and re-illuminated plants. Leaves were infiltrated with $66 \mathrm{mM}$ potassium phosphate buffer ( $\mathrm{pH} 7.0$ ) containing $10 \mathrm{mM} \mathrm{MgCl}$, $100 \mathrm{mM}$ $\mathrm{KCl}, 0.2 \mathrm{mM}$ DTPA and $2 \mathrm{mg} \mathrm{ml}^{-1}$ DTT. Apoplast washing fluid was collected as described previously, with the modification that AWF was collected in empty Eppendorf tubes. Assays were performed immediately. For the determination of G6PDH (EC 1.1.1.49) activity in WLEs, $0.1 \mathrm{~g}$ leaf tissue was ground in $66 \mathrm{mM}$ potassium phosphate buffer ( $\mathrm{pH} 7.0$ ) containing $10 \mathrm{mM} \mathrm{MgCl}_{2}, 0.2 \mathrm{mM} \mathrm{DTPA}$ and $2 \mathrm{mg} \mathrm{ml}^{-1}$ DTT. Extracts were centrifuged at $10,000 \mathrm{~g}$ for $3 \mathrm{~min}$ at $4{ }^{\circ} \mathrm{C}$ and the supernatant recovered. Supernatant was decanted into a fresh Eppendorf tube and the activity of G6PDH determined following the reduction of NADP at $340 \mathrm{~nm}$ at $25^{\circ} \mathrm{C}$ (Kornberg and Horecker 1955). The assay contained $66 \mathrm{mM}$ potassium phosphate ( $\mathrm{pH} 7.6$ ), $10 \mathrm{mM} \mathrm{MgCl}_{2}, 6 \mathrm{mM}$ NADP, $40 \mathrm{mM}$ G6P (to start) and $400 \mu \mathrm{l}$ (50 $\mu \mathrm{l}$ for WLFs). An extinction coefficient of $6.22 \mathrm{mM} \mathrm{cm}^{-1}$ for NADPH at $340 \mathrm{~nm}$ was used to calculate G6PDH activity.

Preliminary experimentation verified the suitability of the acidic buffer for recovery of AWF, the time of infiltration, and the centrifugal force that was optimal for AWF recovery. Optimization for the two different species was based on maximizing the return of AWF and minimizing contamination over a range of centrifugation speeds. The methods employed tend to be species-specific and maybe influenced by variety, growth conditions and leaf age (sensu Moldau et al. 1998; Lyons et al. 1999; Burkey and Eason 2002; Maddison et al. 2002; Padu et al. 2005; Burkey and Carter 2009; Feng et al. 2010). Moreover, the ease with which leaves are infiltrated and AWF recovered is also influenced by the number and size of stomata and mesophyll resistance (O'Leary et al. 2014). Measurements of G6PDH activity revealed less than $0.3 \%$ contamination of AWF by intracellular enzymes, implying the extent of cytosolic contamination of AWF was minimal.

\section{Gas exchange measurements/delivery of equivalent ozone flux day/night}

In a separate experiment, seedlings of $L$. sativa cv Paris Island and $L$. serriola were raised as described elsewhere (Goumenaki et al. 2007). Once the fourth true leaf had begun to emerge, ten plants of each species were placed in four fully randomized blocks inside each of 12 pre-programmable controlled environment chambers. Six chambers were illuminated between 07:00 and 21:00 h. Three of them were ventilated with CFA $\left(<5 \mathrm{nmol} \mathrm{mol}{ }^{-1} \mathrm{O}_{3}\right)$ and three received filtered air plus $\mathrm{O}_{3}$ for $8 \mathrm{~h}$ during the photoperiod (08:00-16:00). The remaining six chambers were illuminated between 17:00 and 07:00 h. Three of these were ventilated with CFA $\left(<5 \mathrm{nmol} \mathrm{mol}^{-1} \mathrm{O}_{3}\right)$ and three received filtered air plus $\mathrm{O}_{3}$ for $8 \mathrm{~h}$ during the dark period (08:00-16:00). After 5 week exposure, 10 plants of each species in each treatment were harvested and the shoots dried in an oven at $70{ }^{\circ} \mathrm{C}$ to constant weight.

Stomatal conductance $\left(g_{\mathrm{H} 2 \mathrm{O}}\right)$ was recorded at $4 \mathrm{~d}$ intervals over the fumigation period ( 5 weeks). Measurements were made in the middle of light or dark period, using a Delta-T porometer on the abaxial surface of the youngest fully expanded leaf of six plants (three per chamber) per variety *treatment combination, alternating between plants exposed to $\mathrm{CFA}$ and $\mathrm{CFA}+\mathrm{O}_{3}$. To undertake measurements in the dark, a green 'safe' light 
$\left(<1 \mu \mathrm{mol} \mathrm{m} \mathrm{m}^{-2} \mathrm{~s}^{-1}\right)$ was employed. These conditions have been shown not to affect stomatal conductance (Kim et al. 2004). Atmospheric ozone concentrations inside each fumigation chamber were adjusted to ensure the delivery of equivalent ozone fluxes, calculated on the basis of recorded $g_{\mathrm{H} 2 \mathrm{O}}$ (Table 2). Ozone flux calculations took account of differences in $\mathrm{O}_{3}$ solubility due to lower night-time temperatures during night-time versus day-time ozone exposure (Table 2; Kosak-Channing and Heiz 1983).

Ozone flux was calculated using Eq. (1), whilst differences in solubility based on temperature differentials were calculated using Eq. (2):

$F_{\mathrm{st}}=\mathrm{c}_{\mathrm{O} 3} * g_{\mathrm{H} 2 \mathrm{O}} * D_{\mathrm{O} 3 / \mathrm{H} 2 \mathrm{O}} * s$,

where $F_{\text {st }}$ represents ozone uptake per unit leaf area (nmol m $\left.\mathrm{m}^{-2} \mathrm{~s}^{-1}\right), \mathrm{c}_{\mathrm{O} 3}$ is the hourly average ozone concentration $\left(\mathrm{nmol} \mathrm{m} \mathrm{m}^{-3}\right), \mathrm{g}_{\mathrm{H} 2 \mathrm{O}}$ is the stomatal conductance to water vapour $\left(\mathrm{m} \mathrm{s}^{-1}\right), \mathrm{D}_{\mathrm{O} 3 / \mathrm{H} 2 \mathrm{O}}$ represents the difference in diffusivity between ozone and water in air (0.613; Nobel $1983)$, and $s$ represents the ozone solubility ratio coefficient in water $(\mathrm{pH} 7)$ :

$\log _{10} s=-0.25-0.013 T$,

where $s$ represents the solubility ratio coefficient in water $(\mathrm{pH} 7)$ and $T$ is temperature $\left({ }^{\circ} \mathrm{C}\right)$.

\section{Statistical analyses}

Statistical analyses were performed using SPSS version 20.0 (IBM, USA). Data were first subjected to ANOVA, investigating the influences of chamber on all measured parameters. No significant chamber to chamber variation was found within treatments, so data were re-analyzed under the assumption that plants in replicate chambers could be grouped within the same datasets. Two-way ANOVA was used to investigate ozone x day/night interactions. Significant differences between means were established using the least significant difference calculated at the $5 \%$ level.

\section{Results}

\section{Characterization of leaf ascorbate content and redox state in plants transferred to darkness and then re-illuminated}

Transfer of 6-week-old plants at the end of a 14-h photoperiod to darkness resulted in a marked and statistically significant $(P<0.001)$ decline in AWF and WLE AA content (in both genotypes) within $12 \mathrm{~h}$ of transfer. Moreover, both these AA pools continued to decline for the duration of a 60-h dark treatment. On transfer of L. sativa plants to the light, AA content increased rapidly and within $2 \mathrm{~h}$ the AA content in both AWF and WLEs had (at least)

Table 2 Stomatal conductance to water vapour $\left(\mathrm{g}_{\mathrm{H} 2 \mathrm{O}}\right)$, temperature, $\mathrm{O}_{3}$ concentrations to which plants were exposed, calculated ozone solubility coefficient and ozone fluxes, during day-time versus night-time exposure of Lactuca sativa cv Paris Island and L. serriola

\begin{tabular}{|c|c|c|c|c|c|c|c|c|c|c|c|}
\hline \multicolumn{7}{|c|}{ Day-time exposure } & \multicolumn{5}{|c|}{ Night-time exposure } \\
\hline Species & Date & $\begin{array}{l}\mathrm{g}_{\mathrm{H} 2 \mathrm{O}}(\mathrm{mmol} \\
\left.\mathrm{m}^{-2} \mathrm{~s}^{-1}\right)\end{array}$ & $\mathrm{T}\left({ }^{\circ} \mathrm{C}\right)$ & $\begin{array}{l}\mathrm{O}_{3}(\mathrm{nmol} \\
\left.\mathrm{mol}^{-1}\right)\end{array}$ & $\begin{array}{l}\text { Solubility } \\
\text { coefficient }\end{array}$ & $\begin{array}{l}\text { Flux (nmol } \\
\left.\mathrm{m}^{-2} \mathrm{~s}^{-1}\right)\end{array}$ & $\begin{array}{l}\mathrm{g}_{\mathrm{H} 2 \mathrm{O}}(\mathrm{mmol} \\
\left.\mathrm{m}^{-2} \mathrm{~s}^{-1}\right)\end{array}$ & $\mathrm{T}\left({ }^{\circ} \mathrm{C}\right)$ & $\begin{array}{l}\mathrm{O}_{3}(\mathrm{nmol} \\
\left.\mathrm{mol}^{-1}\right)\end{array}$ & $\begin{array}{l}\text { Solubility } \\
\text { coefficient }\end{array}$ & $\begin{array}{l}\text { Flux (nmol } \\
\left.\mathrm{m}^{-2} \mathrm{~s}^{-1}\right)\end{array}$ \\
\hline \multirow[t]{7}{*}{ L. sativa } & $10 / 11$ & 180 & 22 & 100 & 0.29 & 11.0 & 35 & 12 & 381 & 0.39 & 11.0 \\
\hline & $15 / 11$ & 197 & 22 & 100 & 0.29 & 12.1 & 85 & 12 & 172 & 0.39 & 12.1 \\
\hline & $20 / 11$ & 197 & 25 & 100 & 0.27 & 12.1 & 29 & 14 & 489 & 0.37 & 12.1 \\
\hline & $25 / 11$ & 179 & 25 & 100 & 0.27 & 11.0 & 57 & 13 & 219 & 0.38 & 11.0 \\
\hline & $30 / 11$ & 117 & 25 & 100 & 0.27 & 7.2 & 59 & 13 & 138 & 0.38 & 7.2 \\
\hline & $5 / 12$ & 178 & 24 & 100 & 0.27 & 10.9 & 100 & 13 & 128 & 0.38 & 10.9 \\
\hline & $10 / 12$ & 189 & 25 & 100 & 0.27 & 11.6 & 54 & 14 & 252 & 0.37 & 11.6 \\
\hline \multirow[t]{7}{*}{ L. serriola } & $10 / 11$ & 346 & 22 & 100 & 0.29 & 21.2 & 61 & 12 & 420 & 0.39 & 21.2 \\
\hline & $15 / 11$ & 160 & 22 & 100 & 0.29 & 9.8 & 118 & 12 & 100 & 0.39 & 9.8 \\
\hline & $20 / 11$ & 160 & 25 & 100 & 0.27 & 9.8 & 46 & 14 & 250 & 0.37 & 9.8 \\
\hline & $25 / 11$ & 158 & 25 & 100 & 0.27 & 9.7 & 40 & 13 & 276 & 0.38 & 9.7 \\
\hline & $30 / 11$ & 137 & 25 & 100 & 0.27 & 8.4 & 22 & 13 & 435 & 0.38 & 8.4 \\
\hline & $5 / 12$ & 111 & 24 & 100 & 0.27 & 6.8 & 24 & 13 & 333 & 0.38 & 6.8 \\
\hline & $10 / 12$ & 96 & 25 & 100 & 0.27 & 5.9 & 26 & 14 & 266 & 0.37 & 5.9 \\
\hline
\end{tabular}

Stomatal conductance was recorded with the aid of a porometer at $4 \mathrm{~d}$ intervals over the fumigation period (5 weeks), on the abaxial surface of the youngest fully-expanded leaf. Values for $g_{\mathrm{H} 2 \mathrm{O}}$ represent the mean of at least six independent measurements. Atmospheric ozone concentrations during night-time exposure to ozone were adjusted to ensure the delivery of equivalent day-time and night-time ozone fluxes (based on day-time exposure of $100 \mathrm{nmol} \mathrm{mol}^{-1} \mathrm{O}_{3}$ ). Fluxes were calculated from recorded $g_{\mathrm{H} 2 \mathrm{O}}$ (see Eq. 1) 
doubled in the majority of cases (Fig. 1). In contrast, AA content recovered slowly following dark-light transition in AWF in L. serriola (Fig. 2). Maintenance of redox state of the AA pool in the apoplast collapsed after $60 \mathrm{~h}$ darktreatment in both species, but both AA content and redox state recovered to pre-dark treatment levels in both species within $24 \mathrm{~h}$ of transfer to the light.

The AA content of apoplast and whole leaf was closely related to the light history of the plant (Figs. 1,2). Interestingly, the depletion of the AA pool in the apoplast
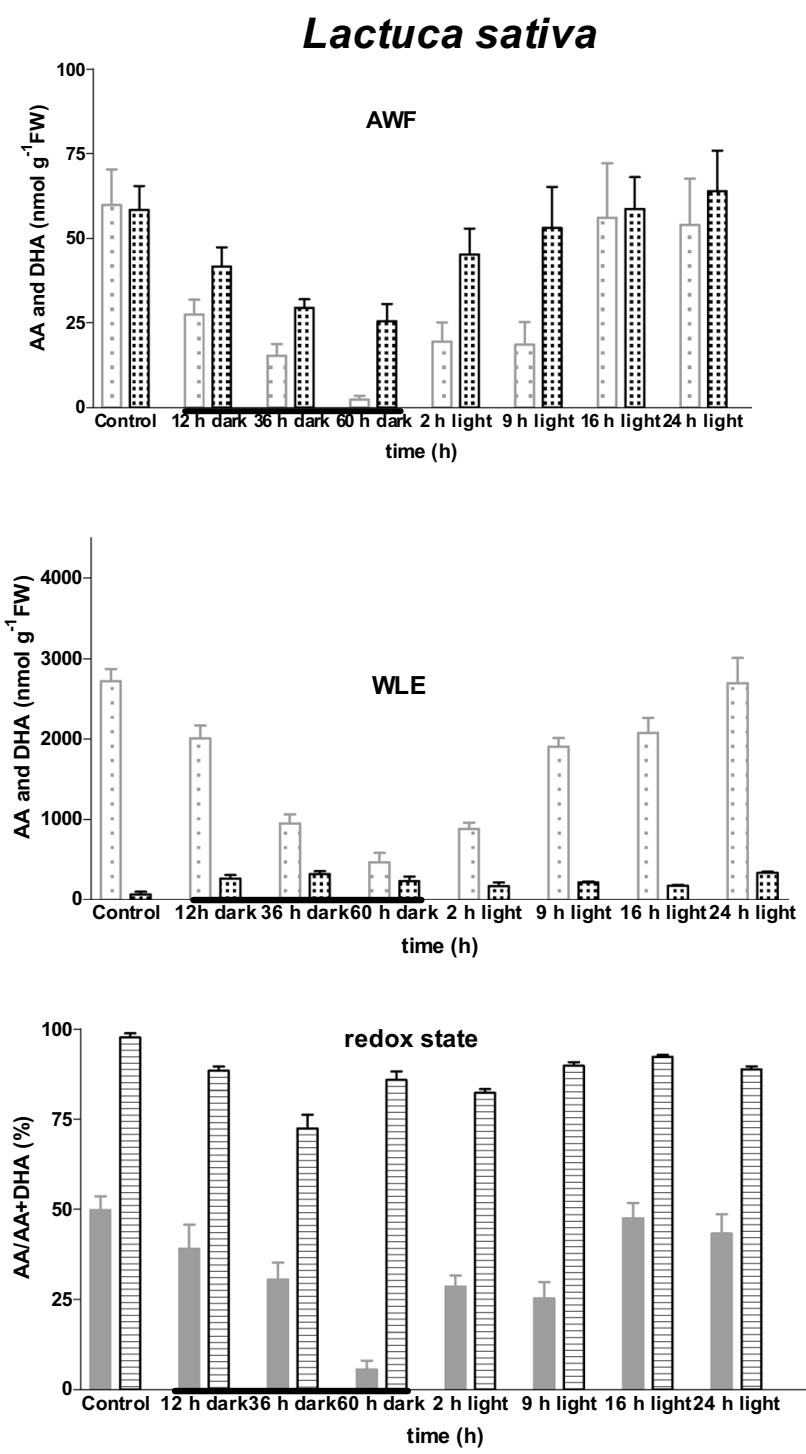

Fig. 1 Impact of light-dark transition on leaf ascorbate content and redox status in Lactuca sativa cv. Paris Island. Measurements of ascorbate (AA 樯) and dehydroascorbate (DHA were made on apoplast washing fluid (AWF ) and whole leaf extracts (WLEs 目) prepared using the most recent fully-expanded leaf of plants raised in controlled environment chambers. Values represent the mean $( \pm \mathrm{SE})$ of eight independent measurements. Thickened portion of $\mathrm{x}$ axis indicates dark period appeared to be more affected by light-dark transition than the whole leaf AA pool. Analysis of variance revealed no statistically significant genotype *dark-treatment interaction, implying a similar response in both genotypes.
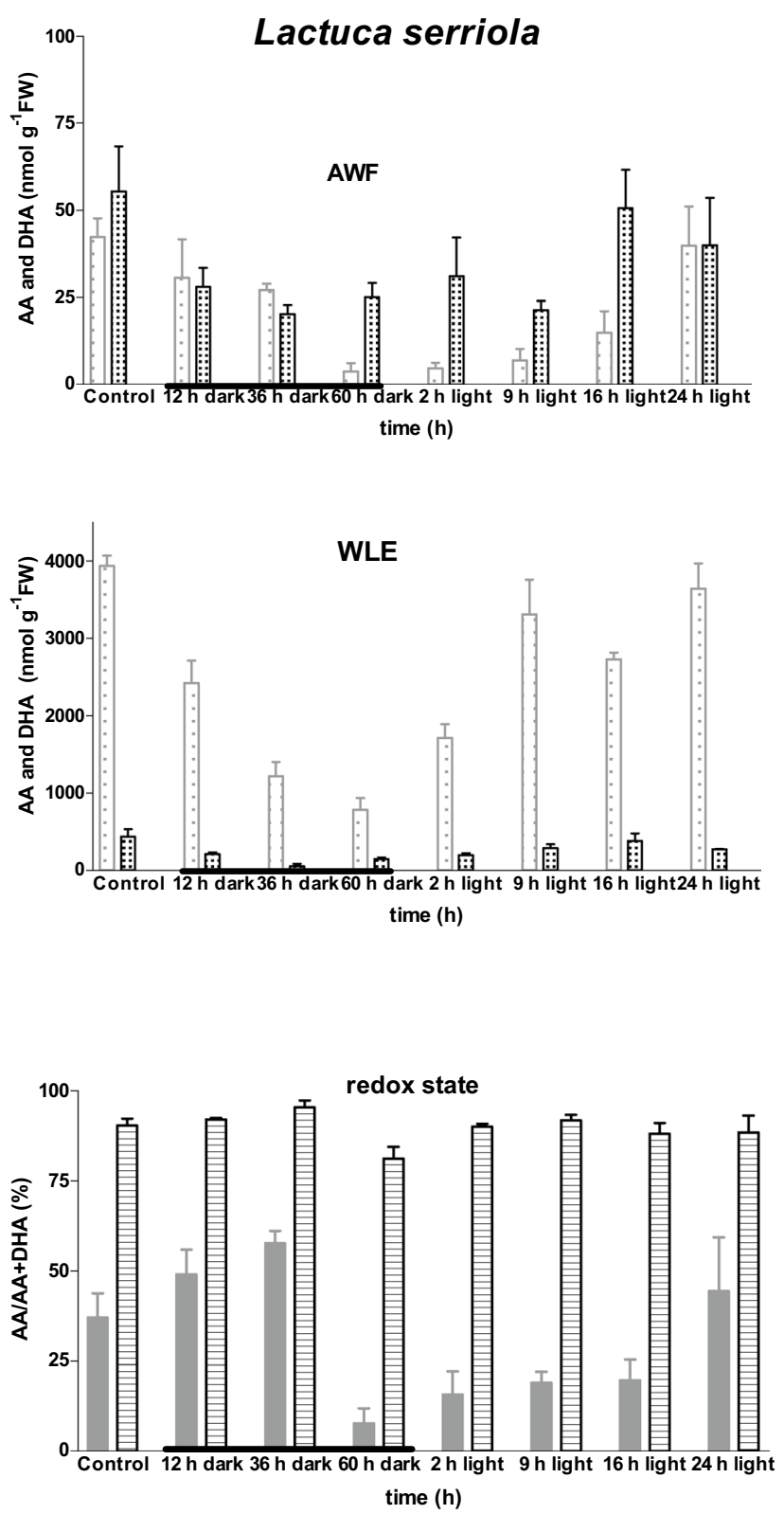

Fig. 2 Impacts of light-dark transition on leaf ascorbate content and redox status in Lactuca serriola. Measurements of ascorbate (AA ) and dehydroascorbate (DHA were made on apoplast washing fluid (AWF ) and whole leaf ex extracts (WLEs 国) prepared using the most recent fully-expanded leaf of plants raised in controlled environment chambers. Values represent the mean $( \pm S E)$ of eight independent measurements. Thickened portion of $\mathrm{x}$ axis indicates dark period 


\section{Assessment of ozone impacts via determination of effects on $A_{\text {sat }}$}

Figure 3 shows the extent of the decline in $A_{\text {sat }}$ triggered by exposure to equivalent ozone flux administered 2,9 , and $24 \mathrm{~h}$ after re-illuminating plants that exhibit a range of AA contents and redox states. The ozone treatment (ozone flux $\left.=36.8 \mathrm{nmol} \mathrm{m}^{-2} \mathrm{~s}^{-1}\right)$ that was administered resulted in a significant $(P<0.05)$ decline in $A_{\text {sat }}$ in both $L$. sativa and $L$. serriola when assayed 2 and $9 \mathrm{~h}$ after re-illumination. Following recovery of AWF AA levels to pre-darkness levels (after $24 \mathrm{~h}$ re-illumination) equivalent ozone uptake resulted in no significant effect on $A_{\text {sat }}$.

\section{Assessment of ozone impacts via determination of effects on growth}

Lactuca sativa and $L$. serriola plants exposed to equivalent ozone fluxes (Table 2) administered during the day-time versus night-time exhibited a significant $(P<0.01)$ decline in biomass under both conditions. Two-way ANOVA revealed a statistically significant ozone *day/night interaction $(P<0.01)$ in both species; biomass losses attributable to equivalent ozone flux were between $10 \%$ and $8 \%$ greater in L. sativa and L. serriola, respectively, when ozone was administered at night versus the day (Fig. 4).

\section{Discussion}

The data reported lend further support to the contention that apoplast AA content and/or redox status govern the sensitivity of plant tissues to ozone-induced oxidative stress (Lyons et al. 1999; Plöchl et al. 2000; Robinson and Britz 2000; Barnes et al. 2002; Pignocchi et al. 2003; Conklin and Barth 2004; Feng et al. 2010; Frei et al. 2008, 2010; Fotopoulos and Kanellis 2013). Our results indicated that when plants were subjected to an ozone episode equating to a flux of $36.8 \mathrm{nmol} \mathrm{m}^{-2} \mathrm{~s}^{-1}$ the reduced ascorbate in the apoplast of $L$. sativa and $L$. serriola maybe sufficient to shield the plasmalemma and/or trigger additional defence mechanisms preventing ozone-induced oxidative damage. In contrast, under conditions, where the apoplast AA pool was depleted (i.e., following short-term re-illumination after prolonged darkness) insufficient protection was afforded so as to prevent a pronounced decline in leaf photosynthetic capacity and resulted to greater biomass losses in both species examined. The implication from these observations is that cell wall-localised AA plays a key role in defining the critical flux threshold for ozone damage.

By carefully managing the ozone exposure in conjunction with measurements of stomatal conductance, it was possible to administer equivalent ozone fluxes during the day and night-time. Ozone concentrations employed at night were unnaturally high, not related to existing or foreseen atmospheric levels, but these concentrations were necessary to achieve equivalent fluxes day and night, given the differences in stomatal conductance under the different conditions, to test the hypothesis under investigation.

Our experimental approach revealed that plants are affected significantly more by equivalent ozone flux takenup at night compared to during the day. This finding is consistent with the theory that detoxification potential is compromised at night (Matyssek et al. 1995; Wieser and Havranek 1995; Musselman and Minnick 2000; Lloyd et al. 2018; Foyer et al. 2020). Our conclusions, that night-time depletion in cell wall-localised ascorbate content and/or redox status may enhance the 'sensitivity' of plants to ozone at night time, are consistent with findings reported by other authors (Moldau et al. 1998; Plöchl et al. 2000; Turcsànyi et al. 2000; Maddison et al. 2002; Burkey and Eason 2002; Sanmartin et al. 2003; Padu et al. 2005; Höller et al 2015). It should not, however, be overlooked that the prolonged dark treatment employed to manipulate AA levels in the present study, as in many others, may trigger a suite of alterations in metabolism in addition to the targeted shift in AA levels (Poór et al. 2018). Such pleiotropic effects were not examined in the present study but warrant further investigation.

In this study L. sativa showed higher biomass loss and higher nocturnal conductance, when exposed to equivalent ozone fluxes at day-time versus night-time, compared to the closest wild species L. serriola. The two species have been shown to exhibit different morphological and physiochemical characteristics, that are reflected in the phyllosphere bacterial community, which can influence plant responses to biotic stress (Hunter et al. 2010; Bailey et al. 2019). Leaf characteristics have been correlated with differential ozone responses in other species (Calatayud et al. 2011; Li et al. 2016). Factors governing the differential response to $\mathrm{O}_{3}$ of the two Lactuca species used in this study remain to be established (see Goumenaki and Barnes, 2009; Goumenaki et al. 2010).

Incomplete stomatal closure at night has been observed in a diverse range of $\mathrm{C}_{3}$ and $\mathrm{C}_{4}$ species (Caird et al. 2007), and night-time exposure can cause significant damage to sensitive plants under some conditions (Musselman and Minnick 2000; Grulke et al. 2004; Mereu et al. 2009; GonzálezFernández et al. 2010). Extensive endeavours to map the risks posed by ozone pollution to terrestrial vegetation are understandably focussed on cumulative stomatal flux during day-time. The results of the present study suggest that some thought should be given to weighing regional models of ozone impacts for extraordinary night-time ozone impacts, since these results showed that from a flux-perspective plants are more sensitive to ozone taken up into foliage at night. The notion that tropospheric ozone metrics used for risk 

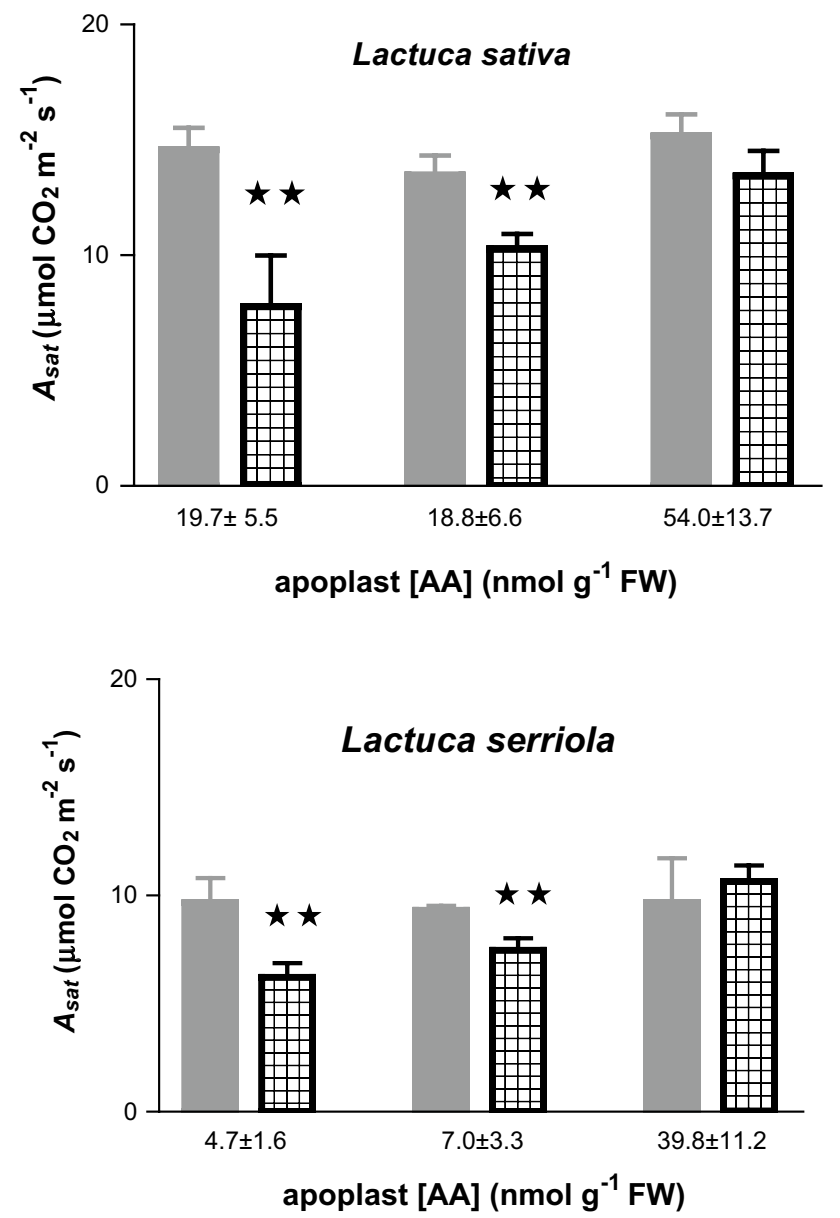

Fig. 3 Ozone-induced decline in light-saturated rate of $\mathrm{CO}_{2}$ assimilation $\left(A_{\text {sat }}\right)$ in foliage of Lactuca sativa cv Paris Island and Lactuca serriola in which the apoplast pool of ascorbic acid was manipulated by the re-illumination of plants for varying periods $(2,9$ or $24 \mathrm{~h})$ following $60 \mathrm{~h}$ darkness. Plants were exposed to CFA $\left(<5 \mathrm{nmol} \mathrm{mol}^{-1}\right.$ $\mathrm{O}_{3}$ ) ( ) or an $\mathrm{O}_{3}$ flux of $36.8 \mathrm{nmol} \mathrm{m} \mathrm{m}^{-2} \mathrm{~s}^{-1}(+)$. Values represent the mean of six independent measurements $( \pm \mathrm{SE})$ made on the most recently full-expanded leaf. Values on $x$-axis represent the mean $\pm \mathrm{SE}$ of initial apoplast AA content. Significant differences from CFA are denoted: $* * P<0.01$

assessment to vegetation should include night-time exposures is also supported by other studies (Musselman and Minnick 2000; Grulke et al. 2004; Mereu et al. 2009; Mills et al. 2018; Hoshika et al. 2019) and could be especially important for the protection of species and communities which often show significant conductance at night, e.g. wetland plant communities and many common tree species. Our findings are consistent with a role for diel shifts in apoplast AA content and/or redox status determining the reaction of plant tissues to ozone-induced oxidative stress. Depletion of the AA pool in the apoplast alters 'sensitivity' to ozone
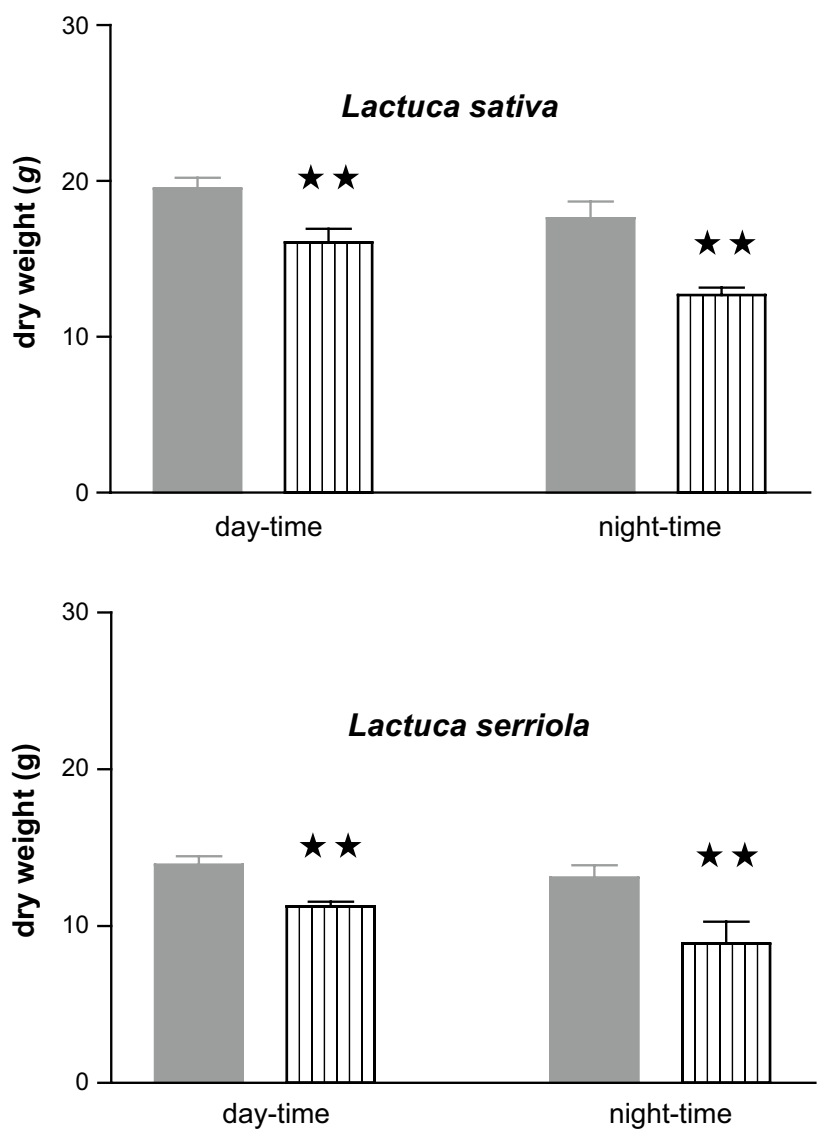

Fig. 4 Impact of equivalent ozone uptake administered during daytime versus night-time on the growth of Lactuca sativa cv Paris Island and L. serriola. Plants were exposed to CFA $\left(<5 \mathrm{nmol} \mathrm{mol}^{-1}\right.$ $\left.\mathrm{O}_{3}\right)(\square)$ or an $\mathrm{O}_{3}$ flux was calculated as shown on Table $2(\square)$ based on aerial concentrations administered daily during 8 h over 5 weeks. Bars represent the mean of ten independent plants per treatment $( \pm$ SE). Significant differences from CFA are denoted: $* * P<0.01$

in a manner that is predictably based on diffusional limitations and biochemical reactions following the uptake of the gas into the leaf interior. Future work is needed to explore the relationship between stress and antioxidants on a quantitative basis in more detail and incorporate detoxification capacity in improved flux-effect models employed for ozone risk assessment.

\section{Conclusions}

The data presented show that apoplast AA content and/ or redox state is subject to day/night control. The adopted experimental approach enabled manipulation of leaf apoplast and symplast ascorbate content to test whether such 
experimental manipulations are linked with shifts in tolerance to short term (acute) $\mathrm{O}_{3}$ exposure. Plants exposed to equivalent ozone fluxes administered during day-time versus night-time exhibited a significant decline in biomass in both cases, and these losses were greater in plants subjected to equivalent ozone flux at night. This observation was consistent with the night-time depletion of cell wall-localised ascorbate.

Author contribution statement EG and JB conceived and designed the research. EG conducted the experiments. EG, IGF and JB analyzed data. EG wrote the manuscript with contributions from all the authors.

Acknowledgements EG is grateful for the support and funding provided by Technological Educational Institute of Crete (currently Hellenic Mediterranean University), and the work was further assisted by additional funding to JB from The Royal Society UK, the EU and the UK Department of the Environment, Food and Rural Affairs. IGF's involvement was supported through JB's EU Framework-funded Marie Curie Training Site (HPMT-CT-2001-00219).

Open Access This article is licensed under a Creative Commons Attribution 4.0 International License, which permits use, sharing, adaptation, distribution and reproduction in any medium or format, as long as you give appropriate credit to the original author(s) and the source, provide a link to the Creative Commons licence, and indicate if changes were made. The images or other third party material in this article are included in the article's Creative Commons licence, unless indicated otherwise in a credit line to the material. If material is not included in the article's Creative Commons licence and your intended use is not permitted by statutory regulation or exceeds the permitted use, you will need to obtain permission directly from the copyright holder. To view a copy of this licence, visit http://creativecommons.org/licenses/by/4.0/.

\section{References}

Agathokleous E, Feng Z, Oksanen E, Sicard P, Wang Q, Saitanis CJ, Araminiene V, Blande JD, Hayes F, Calatayud V, Domingos M, Veresoglou SD, Peñuelas J, Wardle DA, De Marco A, Li Z, Harmens H, Yuan X, Vitale M, Paoletti E (2020) Ozone affects plant, insect, and soil microbial communities: a threat to terrestrial ecosystems and biodiversity. Sci Adv 6(33):1176. https://doi. org/10.1126/sciadv.abc1176

Ainsworth AE, Lemonnier P, Wedow MJ (2020) The influence of rising tropospheric carbon dioxide and ozone on plant productivity. Plant Biol 22(Suppl):5-11. https://doi.org/10.1111/plb.12973

Bailey A, Burkey K, Taggart M, Rufty T (2019) Leaf traits that contribute to differential ozone response in ozone-tolerant and sensitive soybean genotypes. Plants 8(7):235. https://doi.org/10.3390/ plants 8070235

Balaguer L, Barnes JD, Panicucci A, Borland AM (1995) Production and utilization of assimilates in wheat (Triticum aestivum $\mathrm{L}$ ) leaves exposed to elevated $\mathrm{O}_{3}$ and or $\mathrm{CO}_{2}$. New Phytol 129:557568. https://doi.org/10.1111/j.1469-8137.1995.tb03023.x

Barnes JD, Zheng Y, Lyons TM (2002) Plant resistance to ozone: the role of ascorbate. In: Omasa K, Saji H, Yousefian S, Kondo N (eds) Air pollution and plant biotechnology. Springer-Verlag, Tokyo, pp 235-252
Bellini E, De Tullio MC (2019) Ascorbic acid and ozone: novel perspectives to explain an elusive relationship. Plants 8(5):122. https ://doi.org/10.3390/plants8050122

Burkey KO, Carter ET (2009) Foliar resistance to ozone injury in the genetic base of US and Canadian soybean and prediction of resistance in descendent cultivars using coefficient of parentage. Field Crop Res 111:207-217. https://doi.org/10.1016/j.fcr.2008.12.005

Burkey KO, Eason G (2002) Ozone tolerance in snap bean is associated with elevated ascorbic acid in the leaf apoplast. Physiol Plantarum 114:387-394. https://doi.org/10.1034/j.1399-3054.2002.11403 08. $\mathrm{x}$

Caird MA, Richards JH, Donovan LA (2007) Night-time stomatal conductance and transpiration in $\mathrm{C}_{3}$ and $\mathrm{C}_{4}$ plants. Plant Physiol 143:4-10. https://doi.org/10.1104/pp.106.092940

Calatayud V, Cerveró J, Calvo E, García-Breijo FJ, Reig-Armiñana J, Sanz MJ (2011) Responses of evergreen and deciduous Quercus species to enhanced ozone levels. Environ Pollut 159(1):55-63. https://doi.org/10.1016/j.envpol.2010.09.024

Conklin PL, Barth C (2004) Ascorbic acid: a familiar small molecule intertwined in the response of plants to ozone pathogens and the onset of senescence. Plant Cell Environ 27:959-970. https://doi. org/10.1111/j.1365-3040.2004.01203.x

Convention on long-range transboundary air pollution (CLRTAP) (2017) Flux-based critical levels of ozone pollution for vegetation. Overview of new developments. https://icpvegetation.ceh.ac.uk/ publications/thematic. Accessed on 4 February 2020

Dai L, Kobayashi K, Nouchi I, Masutomi Y, Feng Z (2020) Quantifying determinants of ozone detoxification by apoplastic ascorbate in peach (Prunus persica) leaves using a model of ozone transport and reaction. Glob Change Biol 26:3147-3162. https://doi. org/10.1111/gcb.15049

Elvira S, González-Fernández I, Alonso R, Sanz J, Bermejo-Bermejo V (2016) Ozone levels in the Spanish Sierra de Guadarrama mountain range are above the thresholds for plant protection: analysis at 22621850 and $995 \mathrm{~m}$ a.s.1. Environ Monit Assess 188:593. https ://doi.org/10.1007/s10661-016-5581-z

Emberson L (2020) Effects of ozone on agriculture, forests and grasslands. Phil Trans R Soc A 378:20190327. https://doi.org/10.1098/ rsta.2019.0327

Feng Z, Pang J, Nouchi I, Kobayashi K, Yamakawa T, Zhu J (2010) Apoplastic ascorbate contributes to the differential ozone sensitivity of two varieties of winter wheat under fully open-air field conditions. Environ Pollut 158:3539-3545. https://doi.org/10.1016/j. envpol.2010.08.019

Fotopoulos V, Kanellis A (2013) Altered apoplastic ascorbate redox state in tobacco plants via ascorbate oxidase over-expression results in delayed dark-induced senescence in detached leaves. Plant Physiol Biochem 73:154-160. https://doi.org/10.1016/j. plaphy.2013.09.002

Foyer HC, Kyndt T, Hancock DR (2020) Vitamin C in plants: novel concepts new perspectives and outstanding issues. Antioxid Redox Sign 32(7):463-485. https://doi.org/10.1089/ars.2019.7819

Frei M, Tanaka JP, Wissuwa M (2008) Genotypic variation in tolerance to elevated ozone in rice: dissection of distinct genetic factors linked to tolerance mechanisms. J Exp Bot 59:3741-3752. https ://doi.org/10.1093/jxb/ern222

Frei M, Tanaka JP, Chen C, Wissuwa M (2010) Mechanisms of ozone tolerance in rice: characterization of two QTLs affecting leaf bronzing by gene expression profiling and biochemical analyses. J Exp Bot 61:1405-1417. https://doi.org/10.1093/jxb/erq007

Gest N, Garchery C, Gautier H, Jiménez A, Stevens R (2013) Lightdependent regulation of ascorbate in tomato by a monodehydroascorbate reductase localized in peroxisomes and the cytosol. Plant Biotechnol J 11:344-354. https://doi.org/10.1111/pbi.12020

Gillespie C, Stabler D, Tallentire E, Goumenaki E, Barnes J (2015) Exposure to environmentally-relevant levels of ozone negatively 
influence pollen and fruit development. Environ Pollut 206:494501. https://doi.org/10.1016/j.envpol.2015.08.003

González-Fernández I, Kaminska A, Dodmani M, Goumenaki E, Quarrie S, Barnes J (2010) Establishing ozone flux-response relationships for winter wheat: analysis of uncertainties based on data for UK and polish genotypes. Atmos Environ 44(5):621-630. https ://doi.org/10.1016/j.atmosenv.2009.11.021

González-Fernández I, Bermejo V, Elvira S, de la Torre D, González A, Navarrete L, Sanz J, Calvete H, Garcia-Gomez H, Lopez A, Serra J, Lafarga A, Armesto AP, Calvo A, Alonso R (2013) Modelling ozone stomatal flux of wheat under Mediterranean conditions. Atmos Environ 67:149-160. https://doi.org/10.1016/j.atmos env.2012.10.043

González-Fernández I, Calvo E, Gerosa G, Bermejo V, Marzuoli R, Calatayud V, Alonso R (2014) Setting ozone critical levels for protecting horticultural Mediterranean crops: case study of tomato. Environ Pollut 185:178-187. https://doi.org/10.1016/j. envpol.2013.10.033

Goumenaki E, Barnes J (2009) Impacts of tropospheric ozone on growth and photosynthesis of lettuce. Acta Hortic 817:169-176. https://doi.org/10.17660/ActaHortic.2009.817.16

Goumenaki E, González-Fernández I, Papanikolaou A, Papadopoulou D, Askianakis C, Kouvarakis G, Barnes J (2007) Derivation of ozone flux-yield relationships for lettuce: a key horticultural crop. Environ Pollut 146:699-706. https://doi.org/10.1016/j. envpol.2006.08.009

Goumenaki E, Taybi T, Borland A, Barnes J (2010) Mechanisms underlying the impacts of ozone on photosynthetic performance. Environ Exp Bot 69(3):259-266. https://doi.org/10.1016/j.envex pbot.2010.04.011

Grantz DA, Paudel R, Vu H-B, Shrestha A, Grulke N (2016) Diel trends in stomatal response to ozone and water deficit: a unique relationship of midday values to growth and allometry in Pima cotton? Plant Biol 18(Suppl 1):37-46. https://doi.org/10.1111/ plb. 12355

Grulke NE, Heath RL (2020) Ozone effects on plants in natural ecosystems. Plant Biol 22(S1):12-37. https://doi.org/10.1111/ plb.12971

Grulke NE, Alonso R, Nguyen T, Cascio C, Dobrowolski W (2004) Stomata open at night in pole-sized and mature ponderosa pine: implications for $\mathrm{O}_{3}$ exposure metrics. Tree Physiol 24(9):10011010. https://doi.org/10.1093/treephys/24.9.1001

Grünhage L, Pleijel H, Mills G, Bender J, Danielsson H, Lehmann Y, Castell J-F, Bethenod O (2012) Updated stomatal flux and fluxeffect models for wheat for quantifying effects of ozone on grain yield grain mass and protein yield. Environ Pollut 165:147-157. https://doi.org/10.1016/j.envpol.2012.02.026

Höller S, Ueda Y, WuWangHajirezaeiGhaffarivon WirénFrei LYMRM-RNM (2015) Ascorbate biosynthesis and its involvement in stress tolerance and plant development in rice (Oryza sativa L). Plant Mol Biol 88:545-560. https://doi.org/10.1007/s1110 3-015-0341-y

Hoshika Y, De Marco A, Materassi A, Paoletti E (2016) Light intensity affects ozone-induced stomatal sluggishness in snapbean. Water Air Soil Poll 227:419. https://doi.org/10.1007/s11270-016-3127-1

Hoshika Y, De Carlo A, Baraldi R, Neri L, Carrari E, Agathokleous E, Zhang L, Fares S, Paoletti E (2019) Ozone-induced impairment of night-time stomatal closure in $\mathrm{O}_{3}$-sensitive poplar clone is affected by nitrogen but not by phosphorus enrichment. Sci Total Environ 692:713-722. https://doi.org/10.1016/j.scitotenv.2019.07.288

Hunter PJ, Hand P, Pink D, Whipps JM, Bending GD (2010) Both leaf properties and microbe-microbe interactions influence within-species variation in bacterial population diversity and structure in the lettuce (Lactuca Species) phyllosphere. Appl Environ Microbiol 76(24):8117-8125. https://doi.org/10.1128/AEM.01321-10
Kim H, Goins GD, Wheeler RM, Sager JC (2004) Stomatal conductance of lettuce grown under or exposed to different light qualities. Ann Bot-London 94(5):691-697. https://doi.org/10.1093/ aob/mch192

Kopanakis I, Glytsos T, Kouvarakis G, Gerasopoulos E, Mihalopoulos N, Lazaridis M (2016) Variability of ozone in the Eastern Mediterranean during a seven-year study. Air Qual Atmos Health 9:461-470. https://doi.org/10.1007/s11869-015-0362-3

Kornberg A, Horecker BL (1955) Glucose-6-phosphate dehydrogenase. In: Colowick SP, Kaplan NO (eds) Methods in enzymology, vol 1. Academic Press, New York, pp 323-325

Kosak-Channing LF, Heiz GR (1983) Solubility of ozone in aqueous solutions of $0-06 \mathrm{M}$ ionic strength at $5-30{ }^{\circ} \mathrm{C}$. Environ Sci Technol 17:145-149. https://doi.org/10.1021/es00109a005

Kourtidis K, Zerefos C, Rapsomanicis S, Simeonov V, Balis D, Perros PE, Thompson AM, Witte J, Calpini B, Sharobiem WM, Papayannis A, Mihalopoulos N, Drakou R (2002) Regional levels of ozone in the troposphere over eastern Mediterranean. J Geophys Res 107(D18):8140. https://doi.org/10.1029/2000JD000140

Li P, Calatayud V, Gao F, Uddling J, Feng Z (2016) Differences in ozone sensitivity among woody species are related to leaf morphology and antioxidant levels. Tree Physiol 36(9):1105-1116. https://doi.org/10.1093/treephys/tpw042

Lloyd KL, Davis DD, Marini RP, Decoteau DR (2018) Effects of night time ozone treatment at ambient concentrations on sensitive and resistant snap bean genotypes. J Am Soc Hortic Sci 143(1):23-33. https://doi.org/10.21273/JASHS04253-17

Lyons T, Ollerenshaw JH, Barnes JD (1999) Impacts of ozone on Plantago major: apoplastic and symplastic antioxidant status. New Phytol 141:253-263. https://doi.org/10.104 6/j.1469-8137.1999.00338.x

Maddison J, Lyons T, Plöchl M, Barnes JD (2002) Hydroponically-cultivated radish fed L-galactono-1,4-lactone exhibit increased tolerance to ozone. Planta 214(3):383-391. https://doi.org/10.1007/ s004250100625

Matyssek R, Günthardt MS, Maurer S, Keller T (1995) Nighttime exposure to ozone reduces whole-plant production in Betula pendula. Tree Physiol 15:159-165. https://doi.org/10.1093/TREEP HYS/15.3.159

Mavrakis A, Flocas HA, Mavromatidis E, Kallos G, Theoharatos G, Christides A (2010) A case of nighttime high ozone concentration over the greater Athens area. Meteorol Z 19(1):35-45. https://doi. org/10.1127/0941-2948/2010/0428

Mellidou I, Kanellis A (2017) Genetic control of ascorbic acid biosynthesis and recycling in horticultural crops. Front Chem 5:50. https ://doi.org/10.3389/fchem.2017.00050

Mereu S, Gerosa G, Finco A, Fusaro L, Muys B, Manes F (2009) Improved sapflow methodology reveals considerable night-time ozone uptake by Mediterranean species. Biogeosciences 6:31513162. https://doi.org/10.5194/bg-6-3151-2009

Millán MM, Mantilla E, Salvador R, Carratalá A, Sanz MJ, Alonso L, Gangoiti G, Navazo M (2000) Ozone cycles in the western Mediterranean basin: interpretation of monitoring data in complex coastal terrain. J Appl Meteorol 39:487-508. https ://doi.org/10.1175/1520-0450(2000)039\%3c0487:OCITW $\mathrm{M} \% 3 \mathrm{e} 2.0 . \mathrm{CO} ; 2$

Mills G, Pleijel H, Malley SC, Sinha B, Cooper RO, Schultz GM, Neufeld SH, Simpson D, Sharps K, Feng Z, Gerosa G, Harmens H, Kobayashi K, Saxena P, Paoletti E, Sinha V, Xu X (2018) Tropospheric ozone assessment report: present-day tropospheric ozone distribution and trends relevant to vegetation. Elem Sci Anth 6:47. https://doi.org/10.1525/elementa.302

Moldau H, Bichele I, Hüve K (1998) Dark-induced ascorbate deficiency in leaf cell walls increases plasmalemma injury under ozone. Planta 207:60-66. https://doi.org/10.1007/s004250050455 
Musselman RC, Minnick TJ (2000) Nocturnal stomatal conductance and ambient air quality standards for ozone. Atmos Environ 34:719-733. https://doi.org/10.1016/S1352-2310(99)00355-6

Nakano Y, Asada K (1981) Hydrogen peroxide is scavenged by ascorbate-specific peroxidase in spinach chloroplasts. Plant Cell Physiol 22(5):867-880. https://doi.org/10.1093/oxfordjournals. pcp.a076232

Nobel PS (1983) Biophysical plant physiology and ecology. WH Freeman, San Francisco/New York, p 608

Noctor G, Reichheld J-P, Foyer CH (2018) ROS-related redox regulation and signaling in plants. Semin Cell Dev Biol 80:3-12. https ://doi.org/10.1016/j.semcdb.2017.07.013

Ntagkas N, Wolteringa EJ, Marcelis LFM (2018) Light regulates ascorbate in plants: an integrated view on physiology and biochemistry. Environ Exp Bot 147:271-280. https://doi.org/10.1016/j.envex pbot.2017.10.009

O'Leary BM, Rico A, McCraw S, Fones HN, Preston GM (2014) The infiltration-centrifugation technique for extraction of apoplastic fluid from plant leaves using Phaseolus vulgaris as an example. $\mathrm{J}$ Vis Exp 94:52113. https://doi.org/10.3791/52113

Padu E, Kollist H, Tulva I, Oksanen E, Moldau H (2005) Components of apoplastic ascorbate use in Betula pendula leaves exposed to $\mathrm{CO}_{2}$ and $\mathrm{O}_{3}$ enrichment. New Phytol 165:131-142. https://doi.org /10.1111/j.1469-8137.2004.01220.x

Paoletti E, Grulke NE (2010) Ozone exposure and stomatal sluggishness in different plant physiognomic classes. Environ Pollut 158:2664-2671. https://doi.org/10.1016/j.envpol.2010.04.024

Pignocchi C, Fletcher JM, Barnes JD, Foyer CH (2003) The function of ascorbate oxidase (AO) in tobacco (Nicotiana tabacum $\mathrm{L}$ ). Plant Physiol 132:1631-1641. https://doi.org/10.1104/pp.103.022798

Pignocchi C, Kiddle G, Hernandez I, Foster SJ, Asensi A, Taybi T, Barnes JD, Foyer CH (2006) Ascorbate-oxidase-dependent changes in the redox state of the apoplast modulate gene transcription leading to modified hormone signaling and orchestration of defense processes in tobacco. Plant Physiol 141:423-435. https ://doi.org/10.1104/pp.106.078469

Pleijel H, Danielsson H, Emberson L, Ashmore M, Mills G (2007) Ozone risk assessment for agricultural crops in Europe: further development of stomatal flux and flux-response relationships for European wheat and potato. Atmos Environ 4:3022-3040. https ://doi.org/10.1016/j.atmosenv.2006.12.002

Plöchl M, Lyons T, Ollerenshaw J, Barnes JD (2000) Simulating ozone detoxification in the leaf apoplast through the direct reaction with ascorbate. Planta 210:454-467. https://doi.org/10.1007/PL000 08153

Poór P, Ördög A, Czékus Z, Borbély P, Takács Z, Kovács J, Tari I (2018) Regulation of the key antioxidant enzymes by developmental processes and environmental stresses in the dark. Biol Plant 62:201-210. https://doi.org/10.1007/s10535-018-0782-7

Querol X, Alastuey A, Gangoiti G, Perez N, Lee HK, Eun HR, Park Y, Mantilla E, Escudero M, Titos G, Alonso L, Temime-Roussel B, Marchand N, Moreta JR, Revuelta MA, Salvador P, Artíñano B, García dos Santos S, Anguas M, Notario A, Saiz-Lopez A, Harrison RM, Millán M, Ahn K-H (2018) Phenomenology of summer ozone episodes over the Madrid Metropolitan area, central Spain. Atmos Chem Phys 18:6511-6533. https://doi.org/10.5194/ acp-18-6511-2018
Robinson JM, Britz JS (2000) Tolerance of a field grown soybean cultivar to elevated ozone level is concurrent with higher leaflet ascorbic acid level, higher ascorbate-dehydroascorbate redox status and long term photosynthetic productivity. Photosynth Res 64:77-87. https://doi.org/10.1023/A:1026508227189

Royal Society (2008) Ground-level ozone in the 21st century: future trends impacts and policy Implications. Royal Soc Sci Policy Rep 15(08): $148 \mathrm{p}$

Sanmartin M, Drogoudi PD, Lyons T, Pateraki I, Barnes JD, Kanellis AK (2003) Over-expression of ascorbate oxidase in the apoplast of transgenic tobacco results in altered ascorbate and glutathione redox states and increased sensitivity to ozone. Planta 216(6):918-928. https://doi.org/10.1007/s00425-002-0944-9

Strode AS, Ziemke RJ, Oman DL, Lamsal NL, Olsen AM, Liu J (2019) Global changes in the diurnal cycle of surface ozone. Atmos Environ 199:323-333. https://doi.org/10.1016/j.atmosenv.2018.11.028

Takahama U, Oniki T (1992) Regulation of peroxidase-dependent oxidation of phenolics in the apoplast of spinach leaves by ascorbate. Plant Cell Physiol 33(4):379-387. https://doi.org/10.1093/oxfor djournals.pcp.a078265

Turcsànyi E, Lyons T, Plöchl M, Barnes JD (2000) Does ascorbate in the mesophyll cell walls form the first line of defence against ozone? Testing the concept using broad bean (Vicia faba L.). J Exp Bot 51:901-910. https://doi.org/10.1093/jexbot/51.346.901

Ueda Y, Siddique S, Frei M (2015) A novel gene ozone-responsive apoplastic protein1 enhances cell death in ozone stress in rice. Plant Physiol 169(1):873-889. https://doi.org/10.1104/pp.15.00956

Vainonen JP, Kangasjärvi J (2015) Plant signalling in acute ozone exposure. Plant Cell Environ 38(2):240-252. https://doi. org/10.1111/pce.12273

Warmiński K, Bęś A (2018) Atmospheric factors affecting a decrease in the night-time concentrations of tropospheric ozone in a lowpolluted urban area. Water Air Soil Pollut 229:350. https://doi. org/10.1007/s11270-018-4012-x

Wieser G, Havranek WM (1995) Environmental control of ozone uptake in Larix decidua Mill.: a comparison between different altitudes. Tree Physiol 15:253-258. https://doi.org/10.1093/treep hys/15.4.253

Yendrek CR, Koester RP, Ainsworth EA (2015) A comparative analysis of transcriptomic biochemical and physiological responses to elevated ozone identifies species-specific mechanisms of resilience in legume crops. J Exp Bot 66:7101-7112. https://doi.org/10.1093/ jxb/erv404

Zechmann B (2018) Compartment-specific importance of ascorbate during environmental stress in plants. Antioxid Redox Sign 29(15):1488-1501. https://doi.org/10.1089/ars.2017.7232

Zha L, Liu W, Yang Q, Zhang Y, Zhou C, Shao M (2020) Regulation of ascorbate accumulation and metabolism in lettuce by the red:blue ratio of continuous light using LEDs. Front Plant Sci 11:704. https ://doi.org/10.3389/fpls.2020.00704

Publisher's Note Springer Nature remains neutral with regard to jurisdictional claims in published maps and institutional affiliations. 